Safundi

The Journal of South African and American Studies

ISSN: 1753-3171 (Print) 1543-1304 (Online) Journal homepage: http://www.tandfonline.com/loi/rsaf20

\title{
Part IV: Is Die Antwoord Blackface?
}

\section{Adam Haupt}

To cite this article: Adam Haupt (2012) Part IV: Is Die Antwoord Blackface?, Safundi, 13:3-4, 417-423, DOI: $10.1080 / 17533171.2012 .715486$

To link to this article: $\underline{h t t p: / / d x . d o i . o r g / 10.1080 / 17533171.2012 .715486 ~}$

册 Published online: 27 Sep 2012.

Submit your article to this journal $\pi$

Џll Article views: 337

Q View related articles $\square$

4 Citing articles: 1 View citing articles $\square$ 


\title{
PART IV
}

\section{Is Die Antwoord Blackface?}

\author{
Adam Haupt
}

"Brother man, I'm Blacker than you. I'm keeping it real..."

Is Die Antwoord blackface? In a word, yes. During an interview in the US, Waddy Jones reportedly said, "God made a mistake with me. I'm actually black, trapped in a white body." 87 Jones' claim is consistent with his lyrics on "Never le Nkemise" (off their recent album, Ten\$ion): "Ninja, die wit kaffir/Ja, julle naaiers/Skrik wakker" [Ninja, the white kaffir/Yes, you fuckers/Wake up]. ${ }^{88}$ "Kaffir" is a racially pejorative Afrikaans term for a black person and its use in everyday discourse has generally not become as acceptable as the term "nigga," which has featured in the lyrics and interviews of gangsta rappers, like the late Tupac Shakur, or in "hood films," such as Juice (starring Shakur), Menace II Society, or Boyz $N$ the Hood. ${ }^{89}$ Of course, the term "nigga" itself is a contested term and has been the focus of scholarly work, for example, Asim's The $N$ Word, ${ }^{90}$ as well as documentaries such as Larkins' The N Word ${ }^{91}$ and Lazin's Tupac Resurrection. ${ }^{92}$ Whilst, it is entirely possible that Jones is being ironic in the interview and his performances, it is worth noting that he reproduces racially problematic language that signals white, racist projections of blackness.

According to Eric Lott, blackface minstrelsy was developed in the nineteenth century America when "white men caricatured blacks for sport and profit."93 He explains that although "it arose from a white obsession with black (male) bodies, which underlies white racial dread to our own day, it ruthlessly disavowed its fleshy investments through ridicule and racist lampoon." ${ }^{94}$ Lott contends that "the minstrel show had disastrous consequences_-particularly since black people had little room

Correspondence to: Adam Haupt, Centre for Film \& Media Studies, University of Cape Town, Cape Town, South AfricaEmail: Adam.Haupt@uct.ac.za

\footnotetext{
${ }^{86}$ Lee, Bamboozled. While Lee's film is not the focus of this article, it is worth flagging it as an important contribution to critical interrogations of cultural appropriation and the ability of large Hollywood studios to reproduce racial stereotypes on a global scale. Waddy Jones' possibly parodic claim quoted in the opening paragraph of this paper is not unlike the claims of Delacroix's studio executive boss, Dunwitty.

${ }^{87}$ Van Wyk, "Die Antwoord's Ninja: I'm Actually Black," online.

${ }^{88}$ Antwoord, "Never le Nkemise," Ten\$ion.

${ }^{89}$ The term derives from the Arabic word "kafir", which refers to those who do not believe in God (nonbeliever, atheist). Nanji, Dictionary of Islam, 98-9. Also see the Wikipedia entry, Kaffir (racial term), online.

${ }^{5}$ Asim, The $N$ Word.

${ }^{91}$ The $N$ Word, Directed by Larkins.

${ }^{92}$ Tupac Resurrection, Directed by Lazin.

${ }^{93}$ Lott, Love and Theft, 3.

${ }^{94}$ Ibid.
} 


\section{Roundtable on Die Antwoord}

to contest publicly the social meanings generated out of their culture." 95 Therefore, blackface minstrelsy generated a range of meanings that could not be controlled by black subjects, given that they did not have the means to provide competing representations of blackness. Blackface revealed less about black subjects and more about white racist projections of black identities. ${ }^{96}$ Michelle Alexander writes that blackface pandered to white racism and made "whites feel comfortable with-indeed, entertained by-racial oppression." 97 Jonathan Hart describes cultural appropriation as the process by which "a member of another culture takes a cultural practice or theory of a member of another culture as if it were his own or as if the right of possession should not be questioned or contested." 98 For Hart, the unequal relations of power are an important element of this practice:

The debate over cultural appropriation is about whether speaking for others or representing them in fictional as well as legal, social, artistic, and political work is appropriate or proper, especially when individuals or groups with more social, economic, and political power perform this role for others without invitation. This appropriation of culture probably occurred before human records, but it has also been a function of "tribal", national and imperial expansion. ${ }^{99}$

Uneven power differentials produced by the history of colonial domination and imperialism, therefore, play a significant part in the practice of cultural appropriation, particularly in post-apartheid South Africa.

David Hesmondhalgh positions the question of power relationships in relation to marginal communities' contribution to cultural expression on a global scale:

What does it mean, for example, to borrow from the cultures of more vulnerable social groups? What forms of accreditation and recompense are ethically desirable when engaging in such borrowing? These questions are important in any consideration of modern music because, for a variety of social and historical reasons, including the denial of literacy to slave populations, relatively dispossessed peoples have had a proportionately large influence on global popular music. This is most notably true of African-Americans, whose syncretic musics, from jazz to blues to soul to hip-hop, have been the basis of the most globally disseminated sounds. ${ }^{100}$

Hesmondhalgh's argument is that black subjects have often not been acknowledged or rewarded adequately for the extent to which their cultural expressions were appropriated and for the considerable influence of their work upon the world. His reference to the era of slavery and racist exploitation of black labor draws our attention to the uneven bargaining power of black subjects in negotiating white power. Although he offers the history of slavery in the US as an example, one should remember that his discussion also applies to the black experience in South Africa, where colonialism, the enslavement of Africans and diasporic South East Asians,

\footnotetext{
95 Ibid., 102.

${ }^{96}$ Lott, "Blackface and Blackness," 101.

${ }^{97}$ Alexander, The New Jim Crow, 168.

${ }^{98}$ Hart, "Translating and Resisting Empire," 138.

${ }^{99}$ Ibid., 137.

${ }^{100}$ Hesmondhalgh, "Digital Sampling and Cultural Inequality," 55.
} 
as well as legislated apartheid, shaped the agency of black subjects. Relations of power aside, cultural appropriation need not be an intentional distortion of black subjects. As Perry Hall contends, "although whites have consistently been attracted by black rhythmic/musical sensibilities, this attraction is often obscured or distorted by racist habits of thoughts and association that provoke suppression and denial, even while conjuring powerful attractions."101 It is from this perspective, that white representations or projections of blackness reveal more about white subjects than about black identity. In her discussion of the legacy of the minstrel shows in US gangsta rap and "other forms of Blaxploitation," Alexander states that "today's displays are generally designed for white audiences." 102 This situation is not very different from "the minstrel shows of the slavery and Jim Crow eras," she argues. ${ }^{103}$ Not surprisingly, we find that the "majority of consumers of gangsta rap are white, suburban teenagers." 104 This may, in part, explain why Die Antwoord has been so popular in the United States. ${ }^{105}$

Whilst Die Antwoord's parodies reference white and "coloured"106 working-class subjects, it is clear that the artists themselves are far better resourced than the subjects of their work. The set design, props, costumes, cinematography and editing of the band's first music video, "Enter the Ninja," suggest that a great deal of conceptualisation and expertise went into producing this video. The video opens with Ninja addressing the camera directly: "Checkit. Hundred per cent South African culture. In this place, you get a lot of different things. Blacks, whites, coloureds. English, Afrikaans, Xhosa, Zulu, watookal [whatever]. I'm like all these different things, all these different people fucked into one person."107 Before this monologue, there is a close-up shot in which only the left side of his face and naked shoulder are visible in the low-lit set. His head is tilted down and his eyes are closed as he holds his hands to his face, as if in prayer. Shots of tattoos on his body- including an image of cartoon character Richie Rich, accompanied by his name; a hand wielding a knife; and the words "pretty wise" at the base of his throat-flash briefly across the screen, accompanied by eerie sound effects that one normally encounters in horror films or slasher movies. As he begins to speak, we do not see his eyes; we mostly just see his mouth, which draws attention to what appears to be gold fillings in his teeth. In the rapid edit of images, we also see a close-up shot of late hip-hop and visual artist

\footnotetext{
${ }^{101}$ Hall, "African-American Music: Dynamics of Appropriation and Innovation," 34.

${ }^{102}$ Alexander, The New Jim Crow, 168.

${ }^{103}$ Ibid.

104 Ibid.

${ }^{105}$ According to a 2012 entertainment news report, Die Antwoord's US tour was sold out. See Engelbrecht, "Die Antwoord's US Tour Sold Out," online.

${ }^{106}$ I use the term "coloured" in inverted commas in this article to draw attention to the fact that this apartheidera racial category remains contested, even though a large number of subjects self-identify as "coloured"—as opposed to black. My approach to discussions of race is informed by Zimitri Erasmus' argument that all racial identities are socially constructed. Erasmus rejects biologically essentialist understandings of racial identities, particularly ones that position "coloured" identities as a mixture of two presumably pure black and white races. Instead, all racial identities are hybrid. For more detailed discussion of this issue, see Erasmus, "Introduction" and Soudien, Realising the Dream.

${ }^{107}$ Antwoord, "Enter the Ninja."
} 
and DJ Leon Botha, who suffered from a rare disease, progeria; his profile is presumably meant to add to the eeriness produced by the jump cuts and grating sound effects during Ninja's lead-in to the song.

By the end of the monologue, we see Ninja's full profile as he scowls directly at the camera; this shot is alternated with that of Botha. An assortment of references is thus made. Ninja is supposed to seem sinister and menacing by associating the opening scene with the genre of the slasher or horror film, specifically those parts of such films where the edits and sound effects signify that the plot is about to take a violent twist at the hands of a "psycho," a term that he references towards the end of the music video. This appearance is facilitated by the tattoos on his body. Although his accent may mark Ninja, Jones' character, as white, Afrikaans-speaking and working-class, the tattoos allude to Cape Flats gang culture. In fact, the references to the knife, Richie Rich and the graffiti image of Casper the Friendly Ghost wielding a large penis are reminiscent of prison-gang tattoos and gang graffiti. The term "pretty wise" alludes to "raak wys" - a call for people to become wise or "get with the programme." To become wise, in this context, means to become streetwise or to obtain the knowledge that is needed to gain the respect of the gang members. The aesthetic of the tattoos on Ninja's body mimics those of prison-gang tattoos, too, in that they appear to be hand-drawn-as they are in prisons, with the makeshift materials at gang members' disposal. Ninja's tattoos allude to prison tattoos connotatively without actually making denotative connections; the band does not refer directly, but alludes to the numbers gang, the $26 \mathrm{~s}$ and $28 \mathrm{~s}$, via tattoos and the graffiti that appears in the background of their set.

The set design and costumes of Die Antwoord evoke associations with "coloured" gang culture without actually confronting the gritty detail of township life under the shadow of gangs. Ninja's lyrics operate in a similar manner by using terms and expressions associated with Cape Flats gangster-speak: "Trying to fuck up my game with razor sharp lyrical throw-stars, here my flow's hot/ho\$tyle, wild out of control/ ninja skop befokte rof taal [Ninja kicks fucked up rough language], rough rhymes [sic] for tough times." 108 The term "hosh" is a gangster appellation. In this context, "ho\$tyle" alludes to either gangster style or cool style. The use of the dollar sign in Afrikaans blogger Griffin's transcriptions of "Enter the Ninja" is also a reference to gang graffiti, which often employs these symbols in words where the letter " $s$ " is meant to be used. The dollar signs also feature prominently in graffiti on the set where Ninja performs his rap. Two large dollars signs are made up of the images of two s-shaped snakes with swords crossing through them vertically. In addition, the name of the band's debut album, $\$ O \$$, employs these symbols. One could read the repetition of these symbols with Cape gangsters' obsession with the US culture as well as the desire to become rich. The style of the graffiti text also marks neighborhoods as gang territory, and the aesthetic differs noticeably from the wider range of styles, themes, and colours employed by hip-hop graffiti artists when they create murals or simply tag public spaces. In essence, superficial references to

\footnotetext{
${ }^{108}$ Antwoord, "Enter the Ninja," (transcription by www.watkykjy.co.za; online).
} 
Cape gang culture are made in order establish the street credibility of Jones' persona, Ninja. The rap borrows from battle rhymes in its rhetorical aggression and boasts that

Ninja is poes koel, but don't fuck with my game boy

or I'll poes you, life is tough, when I get stuck and my time is up

I push through, till I break-break-break on through to the other side

fantastically poor with patience like the stalker

ninja is hardcore, been cut so deep feel no pain. ${ }^{109}$

The term "poes" is a pejorative term for "vagina"; here, it is used as an adjective that qualifies the term "cool" ("koel"). Ninja's repetitive use of this term, along with other Afrikaans expletives, is meant to position him as "hardcore." Interestingly, however, Die Antwoord's lyrics are actually in English and employ English syntax, while code-switching into Afrikaans and employing Afrikaans expletives. The language, therefore, borrows heavily from non-standard dialects of Afrikaans, while making itself accessible to a wider, English-speaking international audience. The use of certain aspects of Cape Flats dialects of Afrikaans, code-switching, references to kung fu and karate movies and Die Antwoord's spoof of gangster rap form part of the band's parodic intertextuality.

As I have said, it is ironic that the crew's founding member, Waddy Jones, is neither "coloured" nor white Afrikaans working class; rather he is a well-resourced white, English-speaking South African. Die Antwoord's use of the non-standard dialect of Afrikaans that is often spoken in Cape Flats townships, created by the apartheid state's Group Areas Act to separate erstwhile "coloured," white, and black African citizens so that its system of racial categorization became real in the minds of South Africans, amounts to cultural appropriation given that "coloured" subjects themselves have not been able to convert their cultural expressions into symbolic capital. Like Wikus, the protagonist of District 9 who literally becomes an alien in a film that references apartheid-era racism and forced removals in neighborhoods like District Six, ${ }^{110}$ Waddy Jones "goes native" by adopting the Cape Flats dialect of Afrikaans, by acquiring tattoos that reference Cape township gang subcultures and by employing Afrikaans expletives that are stereotypically associated with Cape "coloured" gangsters. Jones' transformation into Ninja of Die Antwoord happens both literally through the transformation of his body with tattoos and figuratively through his use of language. Like Wikus, Jones operates in the tradition of blackface minstrelsy; he needs to "blacken up" to make his performance work. He becomes a "wit kaffir," in other words. 11

The success of District 9 and Die Antwoord teaches us that neo-colonial thinking on racial and gendered identities has local and global appeal, but also that South Africa's transition to democracy has done little to diversify the range of cultural expressions that can reach global audiences, particularly those from the Global

\footnotetext{
${ }^{109}$ Antwoord, "Enter the Ninja."

${ }^{110}$ See Moses, Graham, Marx, Gaylard, Goodman, and Helgesson, "District 9: A Roundtable."

${ }^{111}$ Antwoord, "Never le Nkemise," Ten\$ion.
} 


\section{Roundtable on Die Antwoord}

North. Ultimately, diverse South African subjects' access to the necessary social and economic capital to produce internationally competitive cultural products is constrained by South Africa's neo-liberal economic policies, ${ }^{112}$ which have done little to reduce racialised class inequalities, as well as by hegemonic perceptions of blackness. In essence, this is how a privileged, white, English-speaking South African artist is able to "go native" and become a Web 2.0 viral marketing success story in the US and Europe. ${ }^{113}$

\section{REFERENCES}

Alexander, Michelle. The New Jim Crow: Mass Incarceration in the Age of Colorblindness. London \& New York: The New Press, 2010.

Antwoord, Die. "Enter the Ninja." YouTube video, http://www.youtube.com/watch?v= 8NZBxwjcwMc (accessed February 21, 2012).

Antwoord, Die. Ten\$ion. Zef Records, Universal Music Group, 2012.

Antwoord, Die. "Never le Nkemise." Ten\$ion. Zef Records, Universal Music Group, 2012.

Asim, Jabari. The N Word: Who Can Say It, Who Shouldn't, And Why. Boston \& New York: Houghton Mifflin, 2007.

Bamboozled. Directed by Spike Lee. Forty Acres and a Mule, 2000.

Engelbrecht, T. "Die Antwoord's US Tour Sold Out." Channel24. February 21, 2012, http:// www.channel24.co.za/Music/News/Die-Antwoords-US-tour-sold-out-20120221 (accessed February 22, 2012).

Erasmus, Zimitri. "Introduction: Re-Imagining Coloured Identities in Post-Apartheid South Africa." In Coloured by History, Shaped by Place, edited by Zimitri Erasmus. Cape Town: Kwela Books \& SA History Online, 2001. 13-24.

Gumede, William Mervin. Thabo Mbeki and the Battle for the Soul for the ANC. Cape Town: Zebra Press, 2005.

Hall, P.A. "African-American Music: Dynamics of Appropriation and Innovation.” In Borrowed Power: Essays on Cultural Appropriation, edited by Bruce Ziff and Pratima V. Roa. New Brunswick, NJ: Rutgers University Press, 1997. 31-52.

Hart, J. "Translating and Resisting Empire: Cultural Appropriation and Postcolonial Studies." In Borrowed Power: Essays on Cultural Appropriation, edited by B. Ziff and P.V. Roa. New Brunswick, NJ: Rutgers University Press, 1997. 137-69.

Haupt, Adam. Static: Race \& Representation in Post-Apartheid Music, Media \& Film. Cape Town: HSRC Press, 2012 (forthcoming).

Hesmondhalgh, David. "Digital Sampling and Cultural Inequality." Social \& Legal Studies 15 (2006): 53-75.

Kaffir (racial term). Wikipedia, http://en.wikipedia.org/wiki/Kaffir_\%28racial_term\%29 (accessed June 29, 2012).

Lott, Eric. Love and Theft: Blackface Minstrelsy and the American Working Class. New York \& Oxford: Oxford University Press, 1993.

\footnotetext{
${ }^{112}$ See Gumede, Thabo Mbeki and the Battle for the Soul for the ANC; MacDonald, Why Race Matters in South Africa.

${ }^{113}$ For a more detailed analysis of Die Antwoord, see Haupt, Static. In this book, I pay closer attention to gender politics and also explore debates about the "white trash" race and class stereotype in the performances of Die Antwoord, which is also discussed by Anton Krueger in this roundtable.
} 
—. "Blackface and Blackness: The Minstrel Show in American Culture." In Inside the Minstrel Mask: Readings in Nineteenth-Century Blackface Minstrelsy, edited by James V. Hatch, Brooks McNamara, and Annemarie Bean. Hanover: Wesleyan University Press, 1996. 3-32.

MacDonald, Michael. Why Race Matters in South Africa. Scottsville: University of Kwazulu-Natal Press, 2006.

Moses, Michael Valdez, Lucy Valerie Graham, John Marx, Gerald Gaylard, Ralph Goodman, and Stefan Helgesson. "District 9: A Roundtable." Safundi 11, nos 1-2 (2010): 155-75.

Nanji, Azim. Dictionary of Islam. London, New York \& Johannesburg: Penguin, 2008.

Soudien, Crain. Realising the Dream: Unlearning the Logic of Race in the South African School. Cape Town: HSRC Press, 2012.

The N Word: Divided We Stand. Directed by Todd Larkins. Urban Works Entertainment, 2004.

Tupac Resurrection. Directed by Lauren Lazin. Paramount Pictures, 2004.

Van Wyk, P. "Die Antwoord's Ninja: I'm Actually Black." Channel24. February 17, 2012, http://www.channel24.co.za/Music/News/Die-Antwoords-Ninja-Im-actually-black-20120217 (accessed February 24, 2012).

\section{Editorial Note}

Andrew van der Vlies

Safundi is grateful to the scholars who responded so thoughtfully to my invitation to them to participate in this roundtable, and who were so patient with editorial prompts and suggestions. We record our gratitude, too, to Roelof van Wyk and Roger Ballen, for permission to reproduce their images, which illustrate this roundtable, and to Liese van der Watt and Sean O'Toole for liaising with the photographers on the journal's behalf. 